UMETNOSTNOZGODOVINSKI INŠTITUT FRANCETA STELETA ZRC SAZU

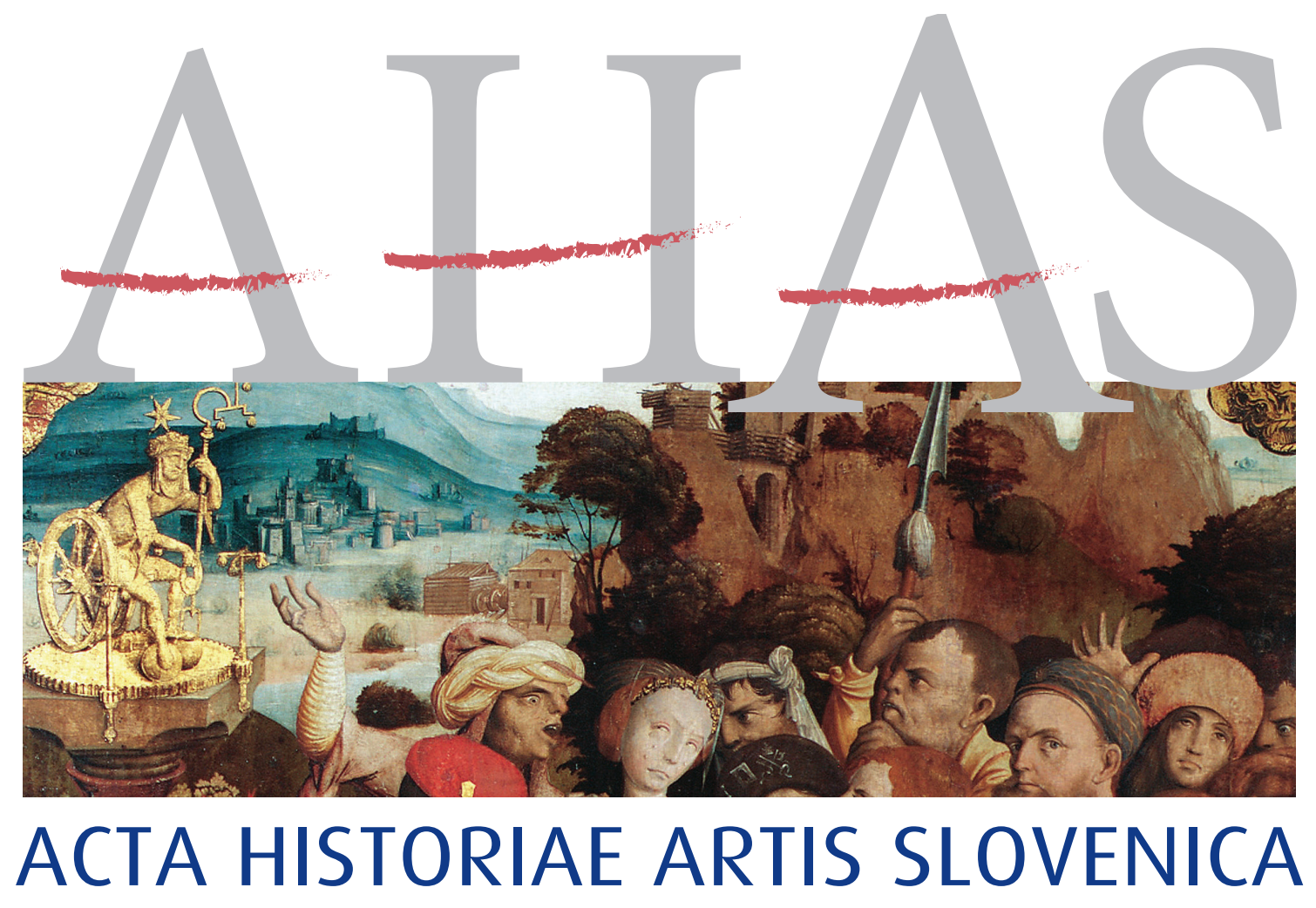


Umetnostnozgodovinski inštitut Franceta Steleta ZRC SAZU

France Stele Institute of Art History ZRC SAZU

\section{ACTA HISTORIAE ARTIS SLOVENICA \\ $24 \mid 1 \cdot 2019$}


Acta historiae artis Slovenica, 24/1, 2019

Znanstvena revija za umetnostno zgodovino / Scholarly Journal for Art History

ISSN 1408-0419 (tiskana izdaja / print edition)

ISSN 2536-4200 (spletna izdaja / web edition)

Izdajatelj / Issued by

ZRC SAZU, Umetnostnozgodovinski inštitut Franceta Steleta /

ZRC SAZU, France Stele Institute of Art History

Založnik / Publisher

Založba ZRC

Glavna urednica / Editor-in-chief

Tina Košak

Uredniški odbor / Editorial board

Renata Komić Marn, Tina Košak, Katarina Mohar, Mija Oter Gorenčič, Blaž Resman, Helena Seražin

Mednarodni svetovalni odbor / International advisory board

Günter Brucher (Salzburg), Ana María Fernández García (Oviedo),

Iris Lauterbach (München), Hellmut Lorenz (Wien), Milan Pelc (Zagreb),

Sergio Tavano (Gorizia-Trieste), Barbara Wisch (New York)

Lektoriranje / Language editing

Aleksandra Čehovin, Amy Anne Kennedy, Blaž Resman, Urška Vranjek Ošlak

Prevodi / Translations

Nika Vaupotič

Oblikovna zasnova in prelom / Design and layout

Andrej Furlan

Naslov uredništva / Editorial office address

Acta historiae artis Slovenica

Novi trg 2, p. p. 306, SI -1001 Ljubljana, Slovenija

E-pošta / E-mail: ahas@zrc-sazu.si

Spletna stran / Web site: http://uifs1.zrc-sazu.si

Revija je indeksirana $v$ / Journal is indexed in

Scopus, ERIH PLUS, EBSCO Publishing, IBZ, BHA

Letna naročnina / Annual subscription: $35 €$

Posamezna enojna številka / Single issue: $25 €$

Letna naročnina za študente in dijake: $25 €$

Letna naročnina za tujino in ustanove / Annual subscription outside Slovenia, institutions: $48 €$

Naročila sprejema / For orders contact

Založba ZRC

Novi trg 2, p. p. 306, SI-1001, Slovenija

E-pošta / E-mail: zalozba@zrc-sazu.si

AHAS izhaja s podporo Javne agencije za raziskovalno dejavnost Republike Slovenije.

AHAS is published with the support of the Slovenian Research Agency.

(C) 2019, ZRC SAZU, Umetnostnozgodovinski inštitut Franceta Steleta, Založba ZRC, Ljubljana

Tisk / Printed by Cicero d. o. 0., Begunje

Naklada / Print run: 400 


\section{VSEBINA \\ Contents}

\section{DISSERTATIONES}

Katarina Šmid

Orfej med živalmi na ptujskem Orfejevem spomeniku - upodobitev ekfraze Filostrata Mlajšega? 7

Orpheus among the Animals on the Orpheus Monument in Ptuj: An Echo of the

Ekphrasis by Philostratus the Younger?

Jure Vuga

Podoba samogibljive skulpture malika, mehaničnega čudesa ali "avtomata na Kranjskem oltarju

A Depiction of a Self-moving Sculpture of an Idol, a Mechanical Marvel or

Automaton in the Krainburg Altarpiece

Boris Golec

Višnjegorski slikarji 17. in 18. stoletja, njihovo socialno in naročniško okolje.

Frančišek Karel (Francesco) Faenzi, Franc Faenzi, Janez Jakob Menhard (Mönhardt),

Jakob Killer, Karel Ludvik Gentilli, Peter Straspurger, Franc Anton Nirenberger,

Franc Ksaver Nirenberger, Anton Nirenberger

$17^{\text {th }}$ and $18^{\text {th }}$ Century Painters from Višnja Gora, their Social Environment and Commissioners.

Franz Karl (Francesco) Faenzi, Franz Faenzi, Johann Jakob Menhard (Mönhardt), Jakob Killer,

Karl Ludwig Gentilli, Peter Straspurger, Franz Anton Nirenberger, Franz Xaver Nirenberger,

Anton Nirenberger.

Renata Komić Marn

"Če bo hotel muzej pridobiti kaj boljših stvari, bo moral za nakup tvegati večje vsote."

Nakupi za Narodni muzej na dražbi Szapáryjeve zbirke v Murski Soboti

"If the museum wishes to obtain better things, it will have to risk higher sums."

The Acquisitions for the National Museum at the Auction of the Szapáry Collection

in Murska Sobota

Barbara Vodopivec

Restitucija predmetov kulturne dediščine iz Avstrije v Jugoslavijo po letu 1945

Restitution of Objects of Cultural Heritage from Austria to Yugoslavia after 1945 


\section{DOCUMENTA}

Jure Volčjak

Cerkve goriške nadškofije na Kranjskem v času nadškofa Karla Mihaela grofa Attemsa.

1. del: Bistrski, gorenjski in metliški arhidiakonat.

The Churches of the Archdiocese of Gorizia in Carniola in the Time of Archbishop

Karl Michael von Attems.

Part 1: The Archdeaconry of Bistra, Upper Carniola (Gorenjska) and Metlika

\section{APPARATUS}

Izvlečki in ključne besede / Abstracts and keywords

Sodelavci / Contributors

Viri ilustracij/ Photographic credits 



\title{
Orfej med živalmi na ptujskem Orfejevem spomeniku - upodobitev ekfraze Filostrata Mlajšega?
}

\author{
Katarina Šmid
}

Od odkritja Pompejev in Herkulaneja v 18. stoletju se je za številne rimske upodobitve mitoloških motivov, zlasti za tiste, ki so se ohranile v več primerkih in relativno sorodnih kompozicijah (npr. Ahil na otoku Skiros, Medeja razmišlja o detomoru), domnevalo, da so nastale na podlagi izgubljenih tabelnih slik in mojstrovin grškega kiparstva, danes poznanih le po rimskih kopijah in literarnih

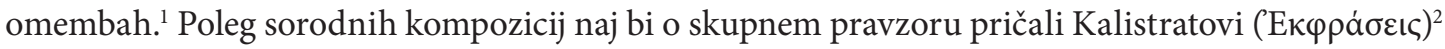
natančni opisi kipov iz 3. ali 4. stoletja ter opisi slik Filostrata Starejšega (Eỉóvec)) iz prve polovice 3. stoletja in Filostrata Mlajšega, znanega tudi kot Filostrat IV. (Eỉóvєৎ), iz druge polovice 3. stoletja ali kasneje. ${ }^{3} \mathrm{Ob}$ tem ne smemo spregledati opisov v delih Homerja, Plinija Starejšega, Pavzanija in drugih. ${ }^{4}$ Nekateri opisi umetnin $\mathrm{v}$ literaturi naj bi se namreč $\mathrm{v}$ številnih podrobnostih ujemali z ohranjenimi stenskimi poslikavami, mozaiki in kiparskimi deli. ${ }^{5}$

1 Gl. Jürgen HODSKE, Mythologische Bildthemen in den Häusern Pompejis. Die Bedeutung der zentralen Mythenbilder für die Bewohner Pompejis, Ruhpolding 2007 (Stendaler Winckelmann-Forschungen, 6), str. 20-21, 108-109.

2 O Kalistratu gl. Balbina BÄBLER, Heinz-Günther NESSELRATH, Ars et Verba. Die Kunstbeschreibungen des Kallistratos, München-Leipzig 2006, str. 5-8, 12-17.

3 O obeh Filostratih gl. Michael SQUIRE, A Picture of Ecphrasis. The Younger Philostratus and the Homeric Shield of Achilles, Gaze, Vision and Visuality in Ancient Greek Literature (ur. Alexandros Kampakoglou, Anna Novokhatko), Berlin-Boston 2018, str. 370-371, op. 31-32. Datacija dela Filostrata Mlajšega je še vedno vprašljiva. Napisal naj bi ga med letoma 250 in 300, novejše raziskave književnih zvrsti pa delo postavljajo šele v zgodnje 4. stoletje (SQUIRE 2018 (op. 3), str. 368-369, op. 25). O življenju Filostrata Mlajšega in njegovi umetnostni formaciji vemo le malo. Gl. Beate NOACK-HILGERS, Philostrat der Jüngere, Gemäldebeschreibungen. Aus der Werkstatt der Analyse seiner Beschreibungstechnik, Thetis. Mannheimer Beiträge zur Klassischen Archäologie und Geschichte Griechenlands und Zyperns, 5/6, 1999, str. 205.

4 Gl. Otto SCHÖNBERGER, Die „Bilder“ des Philostratos, Beschreibungskunst - Kunstbeschreibung. Ekphrasis von der Antike bis zur Gegenwart (ur. Gottfried Boehm, Helmut Pfotenhauer), München 1995, str. 158-160.

5 Na slikarske pravzore naj bi kazale zlasti ekfraze Filostrata Starejšega, ki je, kot pove v proemiju, opisal pinakes iz ene same zasebne zbirke v Neaplju. Šele v drugi polovici 19. stoletja so se pojavili dvomi o tem, ali je tovrstna galerija res obstajala ali pa si je nemara Filostrat vse slike izmislil in naj bi opisi bili zgolj vaje v ekfrazah. Gl. Norman BRYSON, Philostratus and the Imaginary Museum, Art and Text in Ancient Greek Culture (ur. Simon Goldhill), Cambridge 1994 (Cambridge Studies in New Art History and Criticism), str. 255-257; Mario BAUMANN, Bilder schreiben. Virtuose Ekphrasis in Philostrats „Eikones“, Berlin-New York 2011 (Millennium-Studien, 33), str. 94-95. Med drugimi so tovrstno avtentičnost v 19. stoletju zagovarjali Georg Welcker, Heinrich Brunn in Franz Wickhoff, nasprotovali pa so ji Caylus, Karl Friedrichs, Friedrich Matz in Carl Robert. Za historiat debate o avtentičnosti gl. Karl LEHMANN- 
Šele v zgodnjih sedemdesetih letih 20. stoletja so se - sočasno s kritikami starejših interpretacij umetnin, ki so temeljile na iskanju izgubljenih grških originalov v rimskih »kopijah" (t. i. Kopienkritik) ${ }^{6}$ - zlasti med nemškimi klasičnimi arheologi pojavili dvomi o obstoju antičnih pinakotek in pomisleki o tem, da gre v tolikih primerih za naslonitev na neohranjene umetnine. ${ }^{7}$ Danes se stroka bolj nagiba $\mathrm{k}$ mnenju, da so bili natančni opisi le retorične vaje, ki se v nekaterih detajlih ujemajo z ohranjenimi umetniškimi deli. Kljub temu pa paralele med (zlasti slikarskimi) deli in njihovimi opisi $v$ besedilih obeh Filostratov potrjujejo, da sta bila oba gotovo zelo dobro seznanjena s sočasno likovno umetnostjo. Medtem ko so nekateri opisi izrazito podobni ohranjenim upodobitvam, so drugi neprimerno bolj eklektični. ${ }^{8}$

Odkrite mitološke slikarije v Pompejih in Herkulaneju izkazujejo paralele z opisi »slik« (Imagines) Filostrata Starejšega, medtem ko je bil Filostrat Mlajši kot vir upoštevan veliko redkeje. ${ }^{9}$ Veljal je za posnemovalca, če ne že kar epigona, ki je, kot pove tudi sam (Imag. Pr. 1-2), sledil delu svojega eponimnega deda. ${ }^{10}$ Korak k večji veljavi Filostrata Mlajšega predstavlja šele leta 2004 objavljeni zbornik, posvečen njegovim Imagines (Eỉkóveৎ). V njem so opisi posameznih mitoloških prizorov postavljeni ob bok ohranjenim likovnim upodobitvam, pri čemer je poudarek na ohranjenem stenskem slikarstvu Pompejev in Herkulaneja. ${ }^{11}$

V delu Imagines Filostrata Mlajšega je zelo nazorno opisana podoba Orfeja med živalmi, ki naj bi jo videl v zasebni zbirki slik v Neapoli (današnjem Neaplju):

Vsi pisatelji (logopoioi) pravijo, da je Orfej, sin Muze, s svojo glasbo očaral celo bitja, ki niso deležna razuma. In tako pravi tudi slikar: Orfeja nedaleč stran posluša lev, pa tudi merjasec, jelen in zajec, ki ne bežijo pred levovim naskokom. Kar je še v divjini divjih živali, ki se leva bojijo, se zdaj brezskrbne zbirajo skupaj z brezbrižno zverjo. Nikar ne spreglej ptic, pa ne samo pevk, ki navadno ščebetajo po gajih, ne, glej tudi vreščečo,

HARTLEBEN, The Imagines of the Elder Philostratus, The Art Bulletin, 23/ 1, 1941, str. 17-19; BRYSON 1994 (op. 5), str. 257. Za stanje raziskav gl. SCHÖNBERGER 1995 (op. 4), str. 162-163.

6 To metodo je uporabljal zlasti Adolf Furtwängler (1853-1907), ki jo je utemeljeval na primeru grškega in rimskega kiparstva. Gl. Adolf FURTWÄNGLER, Meisterwerke der griechischen Plastik. Kunstgeschichtliche Untersuchungen, Berlin-Leipzig 1893; Adolf FURTWÄNGLER, Ueber Statuenkopieen im Alterthum, München 1896 (Abhandlungen der Königlichen Bayerischen Akademie der Wissenschaften. I. Klasse, 20/3). O Kopienkritik in njenem kritičnem vrednotenju prim. Elaine K. GAZDA, Beyond Copying. Artistic Originality and Tradition, The Ancient Art of Emulation. Studies in Artistic Originality and Tradition from the Present to Classical Antiquity (ur. Elena K. Gazda), Ann Arbor 2002 (Memoirs of the American Academy in Rome. Supplementary Volume, 1), str. 5-8.

7 Gl. Jaś ELSNER, Art and the Roman Viewer. The Transformation of Art from the Pagan World to Christianity, Cambridge 1996 (Cambridge Studies in New Art History and Criticism), str. 24, op. 6-7.

8 Bernhard CÄMMERER, Beiträge zur Beurteilung der Glaubwürdigkeit der Gemäldebeschreibungen des älteren Philostrat, Freiburg im Breisgau 1967, str. 59; Luca GIULIANI, Die unmöglichen Bilder des Philostrat. Ein antiker Beitrag zur Paragone-Debatte?, Pegasus. Berliner Beiträge zum Nachleben der Antike, 8, 2006, str. 94-95, 114; Barbara E. BORG, Rhetoric and Art in Third-Century Rome, Art and Rhetoric in Roman Culture (ur. Jaś Elsner, Michel Meyer), Cambridge 2014, str. 252.

9 Gl. op. 3.

10 Gl. NOACK-HILGERS 1999 (op. 3), str. 204-206; Michael SQUIRE, Ekphrasis at the Forge and the Forging of Ekphrasis. The 'Shield of Achilles' in Graeco-Roman Word and Image, Word \& Image, 29/2, 2013, str. 164-165.

11 Le Immagini di Filostrato Minore. La prospettiva dello storico dell'arte (ur. Francesca Ghedini, Isabella Colpo, Marta Novello), Roma 2004 (Antenor quaderni, 3). Gl. tudi Jaś ELSNER, Ghedini, Francesca, Colpo, Isabella. Le Immagini di Filostrato Minore. La prospettiva dello storico dell'arte, The Journal of Roman Studies, 96, 2006, str. 293, za recenzijo zbornika, ki opozarja na umanjkanje analize literarne tradicije pisanja ekfraz in avtorja kot pisca ter primerjave vizualne umetnosti in retorike podobe. 
vpijočo kavko, pa samega Zevsovega orla; ta je na široko razprl krili, ves napet strmi v Orfeja in se sploh ne zmeni za zajca v bližini, živali pa so, kakor omamljene, zaprtih gobcev povsem v čarodejevi oblasti, volkovi skupaj z ovcami. Še drzneje upodablja slikar drevesa: iztrgal jim je korenine in jih naslikal kot poslušalce, ki stojijo okrog Orfeja. Bor in cipresa, jelša in topol ter vsa druga drevesa so se postavila okoli Orfeja s prepletenimi vejami, kakor da se držijo za roke; niso potrebovala človeških spretnosti, da so zanj spletla gledališče, da bi po vejah lahko posedle ptice, Orfej pa bi lahko skladal v senci. Orfej sedi, na licih mu poganja prvi puh, na glavi mu počiva zlata tiara, v očeh pa blag, a odločen lesk, navdahnjen od boga, ko se um napreza za božanski spev. Morebiti že poje: obrv se mu privzdiguje, kakor da naznanja vsebino pesmi; oblačila spreminjajo barvo z njegovimi gibi. Leva noga počiva na tleh in podpira kitharo, ki sloni na stegnu, desna noga pa $\mathrm{z}$ udarjanjem s sandalom ob tla narekuje ritem. Desna roka trdno drži plektron in si prizadeva za melodijo; komolec je iztegnjen, zapestje je upognjeno navznoter. Leva roka pa $z$ iztegnjenimi prsti brenka na strune. A nekaj nenavadnega se ti bo pripetilo, Orfej! Zdaj res čaraš med zvermi in drevesi, traškim ženskam pa se boš zdel razglašen; raztrgale bodo tvoje telo, četudi so ti divje zveri rade prisluhnile (Imag. 6). ${ }^{12}$

Kakor za večino antičnih ekfraz je tudi za to dolgo veljalo, da naj bi opisovala dejansko tabelno sliko - bodisi grški original ali njegovo zvesto rimsko kopijo. ${ }^{13}$ Natančnejše primerjave z ohranjenimi slikarskimi (v prvi vrsti mozaičnimi) deli rimske dobe pa so pripeljale do teze, da Filostrat Mlajši ni črpal iz likovnih upodobitev, ${ }^{14}$ temveč se je oprl na bogato literarno izročilo številnih avtorjev. ${ }^{15}$ Marsikateri motivni poudarki na nekaterih znanih mozaikih Orfeja med živalmi pa vendarle posredno dokazujejo, da piscu sočasne upodobitve Orfeja med živalmi nikakor niso bile tuje. ${ }^{16}$

Glede na ohranjene primerke lahko sklepamo, da je bil motiv Orfeja med živalmi od sredine 2. stoletja do pozne antike najpogostejši v mozaični umetnosti. Prizori Orfeja med živalmi so predstavljali kompozicijsko in ikonografsko podlago za zgodnjekrščanske upodobitve Jezusa Dobrega pastirja in svetopisemskega kralja Davida, ki sklada psalme in igra na harfo. ${ }^{17}$ Henri Stern je mozaike z upodobitvijo Orfeja med živalmi glede na ikonografske in motivne značilnosti razdelil v tri

12 Za prevod iz stare grščine se najlepše zahvaljujem Gregorju Pobežinu.

13 Gl. Jean THIRION, Orphée magicien dans la mosaïque romaine. A propos d'une nouvelle mosaïque d'Orphée découverte dans la région de Sfax, Mélanges d’archéologie et d'histoire, 67, 1955, str. 170-171; Ursula LIEPMANN, Ein Orpheusmosaik im Kestner-Museum zu Hannover, Niederdeutsche Beiträge zur Kunstgeschichte, 13, 1974, str. 17.

14 O tem naj bi pričala zlasti omemba volkov in ovc, ki se pojavi zgolj v poznem literarnem izročilu. V Filostratovem opisu so med vsemi živalmi samo volkovi in ovce omenjeni v množini, medtem ko v ohranjenih upodobitvah vselej nastopa zgolj po ena žival. Volk in ovca sta upodobljena samo na poznih primerkih in še to nikoli skupaj. Gl. Francesca BARBAZZA, Orfeo, Le immagini di Filostrato Minore (ur. Francesca Ghedini, Issabella Colpo, Marta Novello), Padova 2004 (Antenor quaderni, 3), str. 78, op. 13.

15 O literarnem prikazu prizora gl. BARBAZZA 2004 (op. 14), str. 76-78.

16 Francesca GHEDINI, Filostrato Minore. La prospettiva dello storico dell'arte, Le immagini 2004 (op. 14), str. 184-187.

17 Henri STERN, La mosaique d'Orphee de Blanzy-lès-Fismes, Gallia, 13, 1955, str. 60; Charles MURRAY, Rebirth and Afterlife. A Study of the Transmutation of Some Pagan Imagery in Early Christian Funerary Art, Oxford 1981 (BAR International Series, 100), str. 44; Laurence VIEILLEFON, Les Mosaïques d'Orphée dans les maisons de l'antiquité tardive. Functions décoratives et valeurs religieuses, Mélanges de l'Ecole française de Rome. Antiquité, 116/2, 2004, str. 985-986; Jan BREMMER, Initiation into the Mysteries of the Ancient World, Berlin-Boston 2014 (Münchner Vorlesungen zu antiken Welten, 1), str. 57. 


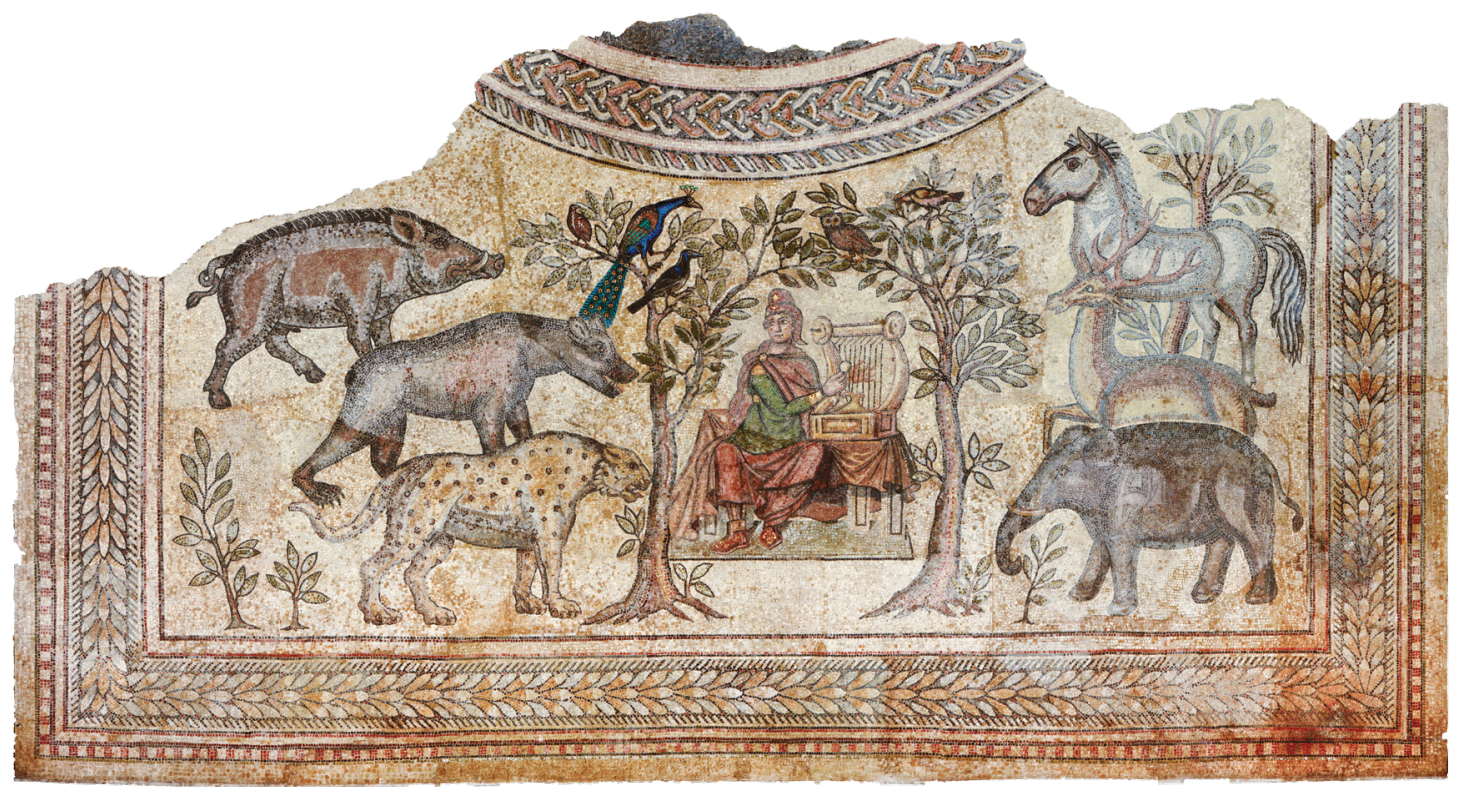

1. Orfej med živalmi, mozaik iz Blanzy-lès-Fismesa, ok. 300-350, Musée archéologique, Laon

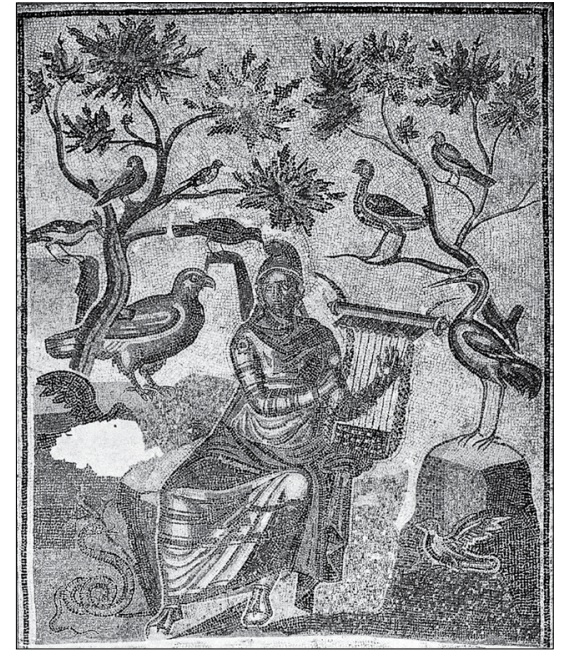

2. Orfej med živalmi, med začetkom 2. in 2. polovico 4. stoletja, Museo de Zaragoza, Zaragoza

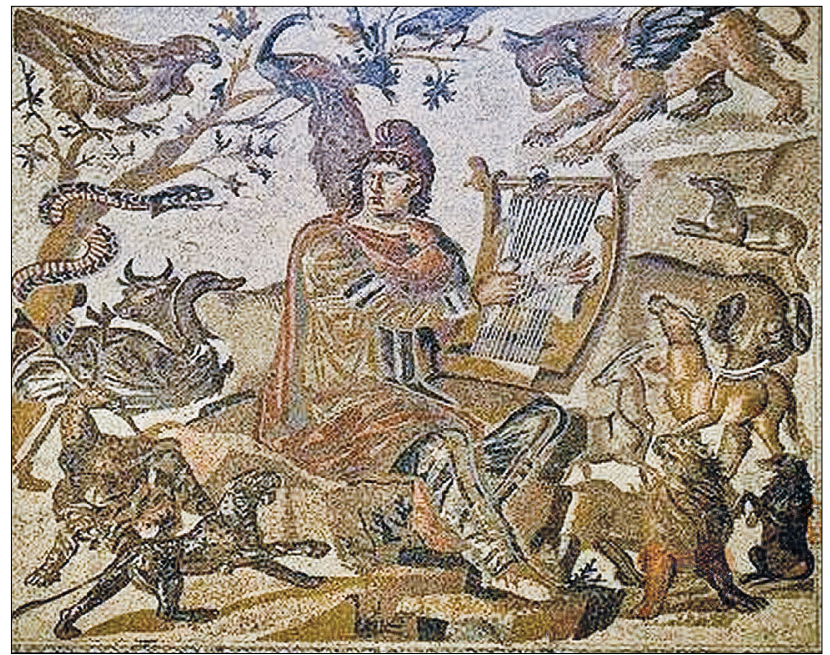

3.Orfej med živalmi, mozaik iz Filipopole, med sredino

3. in začetkom 4. stoletja, Shahba

glavne skupine s podskupinami. ${ }^{18}$ Po njegovem mnenju je največ vzporednic med besedilom Filostratove ekfraze in upodobitvami pri skupini II b, za katero je značilno, da živali pevca obkrožajo $\mathrm{z}$ dveh strani, kot bi bile razdeljene na dva tropa, Orfej pa pripada t. i. frigijskemu tipu. Oblečen je

18 STERN 1955 (op. 17), str. 56-63. Za povzetek starejših razvrstitev gl. Ilona JESNICK, The Image of Orpheus in Roman Mosaic. An Exploration of the Figure of Orpheus in Graeco-Roman Art and Culture with Special Reference to its Expression in the Medium of Mosaic in Late Antiquity, Oxford 1997 (BAR International Series, 671), str. 45-46; Laurence VIEILLEFON, La figure d'Orphée dans l'antiquité tardive. Les mutations d'un mythe du héros païen au chantre chrétien, Paris 2003 (De l’archéologie à l'histoire), str. 52-53. 
v ogrinjalo, kratko tuniko s praviloma dolgimi rokavi in hlače, na glavi pa ima frigijsko čepico. ${ }^{19}$ Sternovo klasifikacijo so kasneje uporabili tudi pri opredeljevanju upodobitev Orfeja med živalmi $\mathrm{v}$ drugih slikarskih in kiparskih zvrsteh.

V maloštevilno skupino II b je Stern uvrstil mozaike iz Blanzy-lès-Fismesa (okoli 300-350, Musée archéologique de Laon, Laon, sl. 1), ${ }^{20}$ Arelata (Arelate; 3. stoletje, Musée de l'Arles antique, Arles), ${ }^{21}$ iz Leptise Magne (Leptis Magna; pozno 2. stoletje, Assaraya Alhamra, Tripoli) ${ }^{22}$ in Cezaravguste (Caesaraugusta; med začetkom 2. stoletja in drugo polovico 4. stoletja, Museo de Zaragoza, sl. 2). ${ }^{23}$ Kasneje so bili v to skupino vključeni še mozaiki iz Tarza (Tarsus; okoli leta 225, Antakya Arkeoloji Müzesi), ${ }^{24}$ Filipopole (Philippopolis) v provinci Arabiji (Shahba, in situ, sl. 3) ${ }^{25}$ vile El Pesquero v Badajozu (druga polovica 4. stoletja, Museo Arqueológico Provincial de Badajoz) ${ }^{26}$ in Kisama (Cisamus) na Kreti (in situ), ${ }^{27}$ poleg njih pa še mozaik s peristila poznoantične rimske hiše v Ptolemaidi (Ptolemais) v Kireni iz poznega 4. oziroma 5. stoletja (in situ). ${ }^{28}$

Stern je menil, da je bila prvotni likovni vir oziroma arhetip te skupine bodisi tabelna slika, ki jo opisuje Filostrat Mlajši, ali pa neko starejše delo, po katerem je bila povzeta, ki pa ni nastalo pred začetkom antoninske oziroma severske dobe. Od ohranjenih mozaikov naj bi bil arhetipu najbližji tisti iz Leptise Magne. ${ }^{29}$

19 STERN 1955 (op. 17), str. 56-59.

20 Otto GRUPPE, Orpheus, Ausführliches Lexikon der griechischen und römischen Mythologie, 3, Leipzig 1884, str. 1191; Giacomo GUIDI, Orfeo, Liber Pater e Oceano in mosaici della Tripolitania, Africa Italiana, 6, 1935, str. 121, kat. št. 1; Victorine von GONZENBACH, Drei Orpheusmosaiken aus der Waadt, Jahrbuch der Schweizerischen Gesellschaft für Urgeschichte/Annuaire de la Société suisse de préhistoire/Annuario della Società svizzera di preistoria, 40, 1949/50, str. 284; STERN 1955 (op. 17), str. 41-49, 60-63; Felix M. SCHOELLER, Darstellungen des Orpheus in der Antike, Freiburg 1969, str. 31; Enrique R. PANYAGUA, Catálogo de representaciones de Orfeo en el arte antiguo. 3. Escultura helenística y romana, pintura romana, mosaicos, miniaturas, Helmantica, 24, 1973, str. 470-471, kat. št. 211; LIEPMANN 1974 (op. 13), str. 27, kat. št. 14; Janine BALTY, La mosaïque d’Orphée de Chahba-Philippopolis, Mosaïque. Recueil d'hommages à Henri Stern, Paris 1983, str. 34-35; Maria-Xeni GAREZOU, Orpheus, Lexicon Iconographicum Mythologiae Classicae, 7/1, Zürich-München-Düsseldorf 1994, str. 91, kat. št. 111; JESNICK 1997 (op. 18), str. 47, 68, 135, kat. št. 38; VIEILLEFON 2003 (op. 18), str. 169, kat. št. F2.

21 STERN 1955 (op. 17), str. 68, kat. št. 2; SCHOELLER 1969 (op. 20), str. 39, kat. št. 44; LIEPMANN 1974 (op. 13), str. 26, kat. št. 4; GAREZOU 1994 (op. 20), str. 91, kat. št. 104.

22 BALTY 1983 (op. 20), str. 34. O mozaiku gl. STERN 1955 (op. 17), str. 72, kat. št. 25; PANYAGUA 1973 (op. 20), str. 491-492, kat. št. 246; LIEPMANN 1974 (op. 13), str. 28, kat. št. 36; GAREZOU 1994 (op. 20), str. 90-91, kat. št. 97; JESNICK 1997 (op. 18), str. 129, kat. št. 9; VIEILLEFON 2003 (op. 18), str. 166, kat. št. A16.

23 STERN 1955 (op. 17), str. 71-72, kat. št. 20; SCHOELLER 1969 (op. 20), str. 38, kat. št. 39; PANYAGUA 1973 (op. 20), str. 473, kat. št. 219; LIEPMANN 1974 (op. 13), str. 28, kat. št. 45; JESNICK 1997 (op. 18), str. 134, kat. št. 34; GAREZOU 1994 (op. 20), str. 92, kat. št. 123b; VIEILLEFON 2003 (op. 18), str. 169, kat. št. Pi11.

24 PANYAGUA 1973 (op. 20), str. 495-496, kat. št. 254; LIEPMANN 1974 (op. 13), str. 26, kat. št. 3; BALTY 1983 (op. 20), str. 35; JESNICK 1997 (op. 18), str. 140, kat. št. 67.

25 Gl. op. 37-39.

26 GAREZOU 1994 (op. 20), str. 92, kat. št. 123a.

27 GAREZOU 1994 (op. 20), str. 94, kat. št. 134.

28 Richard Martin HARRISON, An Orpheus Mosaic at Ptolemais in Cyrenaica, The Journal of Roman Studies, 52/12, 1962, str. 13-18; SCHOELLER 1969 (op. 20), str. 38, kat. št. 33; PANYAGUA 1973 (op. 20), str. 492-493, kat. št. 248; LIEPMANN 1974 (op. 13), str. 28, kat. št. 34; BALTY 1983 (op. 20), str. 35; JESNICK 1997 (op. 18), str. 142, kat. št. 74.

29 STERN 1955 (op. 17), str. 59-60. 


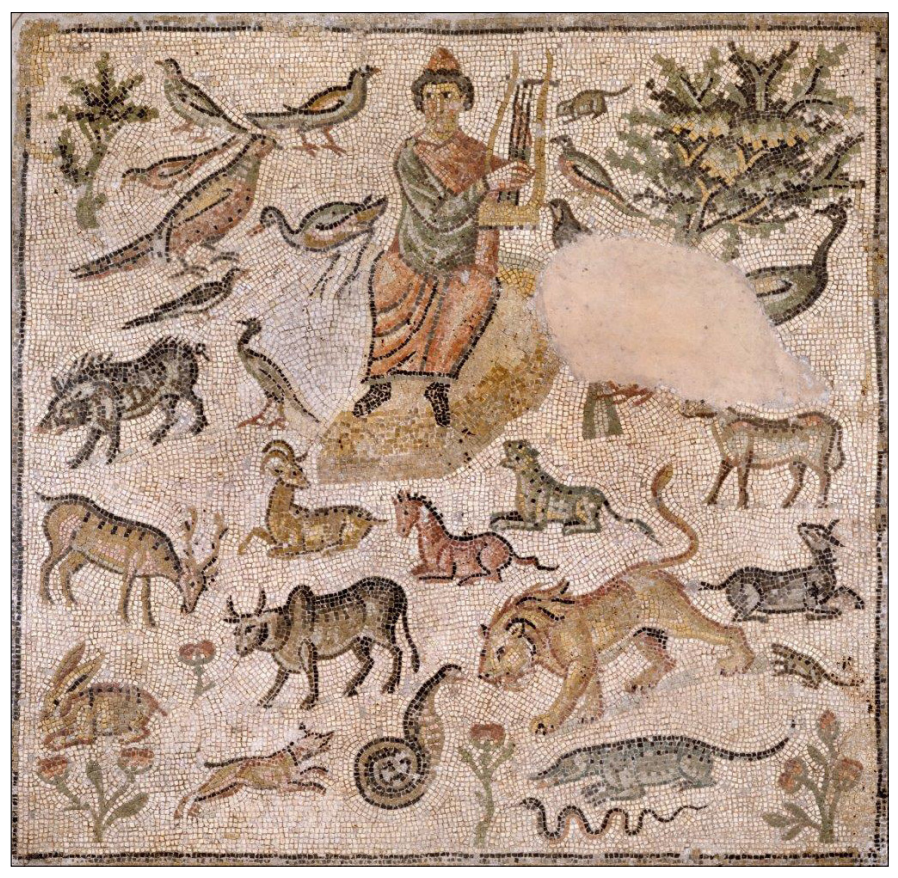

4. Orfej med živalmi, 397,

Museum August Kestner, Hannover

Del besedila iz Filostratove ekfraze z motivom dreves okoli pevca, ki stikajo svoje veje nad prizoriščem, da se nanje lahko posedejo ptice, ${ }^{30}$ je na ohranjenih upodobitvah izjemno redek:

Bor in cipresa, jelša in topol ter vsa druga drevesa so se postavila okrog Orfeja s prepletenimi vejami, kakor da se držijo za roke /.../ zanj spletla gledališče, da bi po vejah lahko posedle ptice /.../ (Imag. 6).

Stern je ta del opisa primerjal z mozaiki iz skupine II b, pri čemer je posebej izpostavil upodobitev iz Blanzy-lès-Fismesa (Musée archéologique de Laon, sl. 1), na kateri se Filostratovemu opisu približa Orfejevo pokrivalo, ki ga ožarjajo zlate mozaične kocke. ${ }^{31}$ Sternove ugotovitve je nadgradila Janine Balty, ki je o mozaikih v Zaragozi (sl. 2) in Laonu poudarila, da zvesto ponavljata v ekfrazi opisano shemo dreves, ki nad pevcem sklenejo veje kot dlani in tako ustvarijo "gledališče ${ }^{32}$

Ursula Liepmann je opozorila na podobnost številnih detajlov iz ekfraze z mozaikom iz neznanega najdišča v severni Siriji (Museum August Kestner, Hannover, sl. 4), datiranim v leto 397. ${ }^{33}$ Pri tem je izpostavila tiaro na glavi, ${ }^{34}$ plašč, levo nogo, ki počiva na tleh, in desno, ki daje takt, ter navznoter upognjeno desno dlan, s katero drži plektrum, medtem ko z levico brenka po kithari, ki jo

30 Drevo, na katerem sedijo ptice, sicer nastopa na skoraj vseh mozaikih z upodobitvijo Orfeja med živalmi (BALTY 1983 (op. 20), str. 35), a le na mozaikih iz Blanzy-lès-Fismesa in Cezaravguste na vsaki strani pevca raste po eno drevo, veje pa se stikajo nad njim.

31 STERN 1955 (op. 17), str. 60; prim. BARBAZZA 2004 (op. 14), str. 81.

32 BALTY 1983 (op. 20), str. 35-36. Za njo je te ugotovitve sprejela še BARBAZZA 2004 (op. 14), str. 80-81.

33 LIEPMANN 1974 (op. 13), str. 21; GAREZOU 1994 (op. 20), str. 92, kat. št. 124. Za reprodukcijo se najlepše zahvaljujem muzeju Museum August Kestner.

34 Tiara verjetno pomeni frigijsko čepico, saj Filostrat Mlajši ta izraz uporablja tudi pri opisih »vzhodnjakov« Ganimeda (Imag. 8.1) in Pelopsa (Imag. 9.1). Gl. BARBAZZA 2004 (op. 14), str. 79-80, op. 27. 
podpira $\mathrm{z}$ levim stegnom. ${ }^{35}$ Edini očitni razliki med opisom in upodobitvijo naj bi bili kithara, ki jo Orfej na mozaiku drži v višini prsi, in manjkajoči plektrum. ${ }^{36}$ Poudariti je treba, da so podobnosti, ki jih izpostavlja Liepmannova, zelo splošne in jih najdemo na skoraj vseh prizorih skupine II b ter še na številnih drugih mozaikih, v redkejših detajlih, kot so npr. že omenjena drevesa, ki se bočijo nad pevcem, pa se ekfraza ne ujema s sirskim mozaikom. Prav tako je avtorica povsem zanemarila kolorit, ki bi se le pogojno lahko ujemal z opisom, saj na njem na primer ni sledov brade, Orfejevo pokrivalo ni zlato ožarjeno, barve na oblačilu pa se ne prelivajo.

Več vzporednic s Filostratovim opisom razkriva mozaik v Filipopoli v provinci Arabiji (Shahba, in situ, sl. 3), ${ }^{37}$ ki je v literaturi datiran $\mathrm{v}$ čas od začetka vladavine Filipa Arabca (244-249) do konca 3. stoletja, ${ }^{38}$ pri nekaterih piscih pa celo v 4. stoletje. ${ }^{39}$ Mozaik se $\mathrm{z}$ besedilom ujema tako v liku Orfeja in koloritu (entuziazem, ki ga navdihuje, njegova drža, oblačila, prvi znaki brade, z zlatom obsijano pokrivalo,

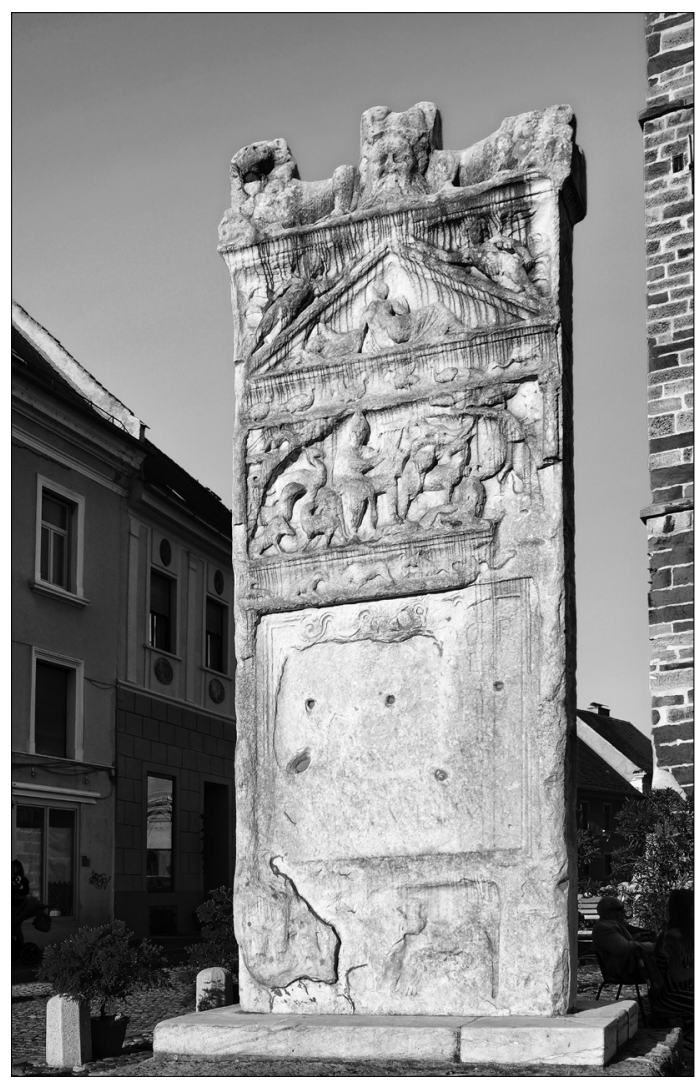

5. Orfejev spomenik na Ptuju, 3. stoletje menjajoči se odtenki rdeče na plašču) kot tudi v živalih, ki ga obdajajo (divje in krotke živali, zbrane okoli glasbenika). ${ }^{40}$

Več motivnih elementov iz Filostratove ekfraze vključuje tudi osrednji relief na Orfejevem spomeniku, ${ }^{41}$ nagrobni steli petovionskega duovira in dekuriona (in situ; sl. 5-6). ${ }^{42} \mathrm{Na}$ njem so

35 LIEPMANN 1974 (op. 13), str. 15-17.

36 LIEPMANN 1974 (op. 13), str. 15-17.

37 Na sorodnosti med ekfrazo in mozaikom v Filipopoli je prva opozorila BALTY 1983 (op. 20), str. 35-36. Gl. tudi BARBAZZA 2004 (op. 14), str. 80-81.

38 Claudine M. DAUPHIN, A Roman Mosaic Pavement from Nablus, Israel Exploration Journal, 29/1, 1979, str. 30-31; JESNICK 1997 (op. 18), str. 141, kat. št. 70.

39 Gl. Janine BALTY, Mosaiques antiques de Syrie, Bruxelles 1977, str. 44; BALTY 1983 (op. 20), str. 36-37, za relativno pozno datacijo, $v$ prvo desetletje oziroma $v$ drugo četrtino 4 . stoletja. V prvo polovico 4 . stoletja ga datirata tudi GAREZOU 1994 (op. 20), str. 92, kat. št. 116; VIEILLEFON 2003 (op. 18), str. 181, kat. št. Or12.

40 BALTY 1983 (op. 20), str. 35-36; BARBAZZA 2004 (op. 14), str. 80-81.

41 Temeljno znanstveno razpravo je prispeval Alexander CONZE, Römische Bildwerke einheimischen Fundorts in Österreich. Sculpturen in Pettau und St. Martin am Pacher, 2, Wien 1875 (Denkschriften der kaiserlichen Akademie der Wissenschaften). Gl. tudi strokovno monografijo Katarina ŠMID, Orfejev spomenik na Ptuju, Ljubljana 2019 (Umetnine v žepu, 16). Za napis na steli gl. Géza ALFÖLDY, Die Valerii in Poetovio, Arheološki vestnik, 15-16, 1964-1965, str. 137-144; Géza ALFÖLDY, Epigraphica, Situla, 8, 1965, str. 93-112; Marjeta ŠAŠEL KOS, Petovionska vladajoča aristokracija, Ptujski arheološki zbornik. Ob 100-letnici muzeja in muzeološkega društva, Ptuj 1993, str. 219-232.

42 Med obnovo cestišča v devetdesetih letih 20. stoletja so bili približno 20 metrov od spomenika odkriti temelji, ki bi lahko pripadali tej steli (Janez MIKUŽ, Giancarlo CALCAGNO, Restavriranje Orfejevega spomenika na Ptuju, Letno poročilo. Zavod za varstvo naravne in kulturne dediščine Maribor. 1997, Maribor 1999, str. 13). 


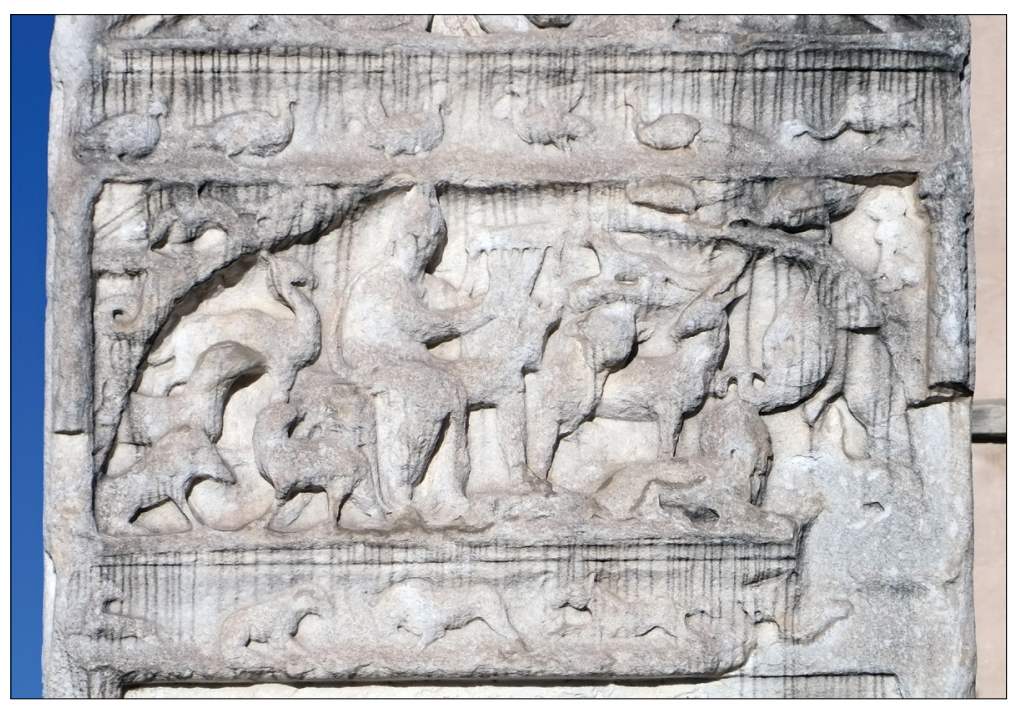

6. Orfej med živalmi na Orfejevem spomeniku, Ptuj

upodobljene živali, ki jih omenja Filostrat (lev, merjasec, volk, ovca, ptice), izrazito podobne opisom v ekfrazi pa so tudi drevesne veje s pticami nad prizoriščem in Orfejeva drža. Paralel z ekfrazo je na ptujskem spomeniku celo več, kot jih izkazujejo mozaiki iz skupine II b in mozaik iz Filipopole.

Številni avtorji opredeljujejo prizorišče na petovionski steli kot votlino oziroma prostor, ki nanjo spominja, ${ }^{43}$ kar verjetno izvira iz opazke »ist wie von einer Grotte überwölbt « ${ }^{44}$ nemškega klasičnega arheologa Alexandra Conzeja (1831-1914), ki je o tej steli napisal prvo poglobljeno in celostno razpravo. Motiv ptic in opice, ki mirujejo na vrhu polkrožno zaključenega prizorišča, pa kaže na to, da je prizor verjetneje umeščen pod drevesne krošnje. Veji se nad prizoriščem bočita tudi na - sicer ne v vseh podrobnostih natančni - risbah ptujskega kurata in zgodovinarja Simona Povodna (1753-1841, sl. 7-8). ${ }^{45}$

Medtem ko slaba ohranjenost otežuje natančnejšo analizo osrednjega prizora na ptujskem reliefu, so sorodnosti lažje prepoznavne na steli Avrelija Kalandina, veterana Prve asturske kohorte. ${ }^{46}$ Nagrobnik se je ohranil vzidan v zunanjo steno župnijske cerkve sv. Martina na Šmartnem na Pohorju. Pokojnikova kohorta je bila na koncu 2. in v začetku 3. stoletja nameščena v kastelu Astura

43 Prim. Viktor HOFFILLER, Balduin SARIA, Antike Inschriften aus Jugoslawien. 1: Noricum und Pannonia Superior, Zagreb 1938, str. 175-177, kat. št. 389; Michael ABRAMIĆ, Poetovio. Führer durch die Denkmäler der römischen Stadt, Wien 1925, str. 135; Jože KASTELIC, Simbolika mitov na rimskih nagrobnih spomenikih. Šempeter $v$ Savinjski dolini, Ljubljana 1998, str. 485; Mojca VOMER GOJKOVIČ, Women from Poetovio, Datiranje kamenih spomenika i kriteriji za odredivanje kronologije. Akti 12. medunarodnog kolokvija o rimskoj provincijalnoj umjetnosti, Pula 2014, str. 151.

44 CONZE 1875 (op. 41), str. 7.

45 Steiermärkisches Landesarchiv (StLA), Handschriftensammlung, Hs 824 Antiquitaten Poetoviens, Simon Povoden, Abbildungen der römischen Votiv- und Begrabungstteine samt einer Erklärung, Pettau 1830, št. 28; Steiermärkisches Landesarchiv (StLA), Handschriftensammlung, Hs 180, Simon Povoden, Abbildungen aller in Pettau und dessen Umgegend befindlichen Denksteine nebst einer gewagten Erklärung ihrer Aufschriften, Pettau 1832, št. 26.

${ }^{46}$ Gl. Peter WEIß, Zwei vollständige Konstitutionen für die Truppen in Noricum (8. Sept. 79) und Pannonia inferior (27. Sept. 154), Zeitschrift für Papyrologie und Epigraphik, 146, 2004, str. 246, op. 28. 

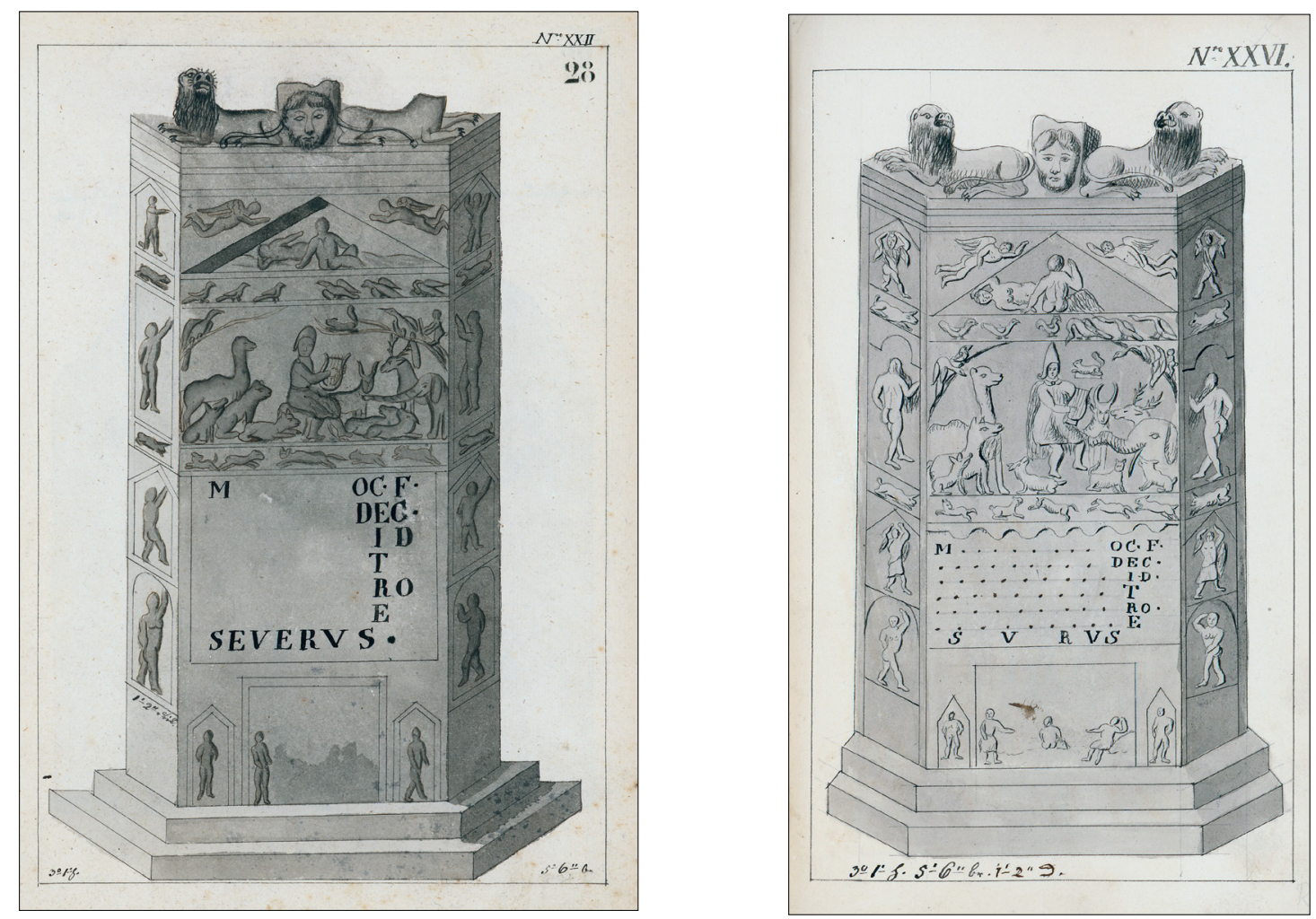

7.-8. Simon Povoden: risbi Orfejevega spomenika, 1830-1832, Steiermärkisches Landesarchiv, Graz

(zdaj Zeiselmauer ali Zwentendorf v Spodnji Avstriji). ${ }^{47}$ Stela v motivno nekoliko reducirani ${ }^{48}$ in pomanjšani obliki sledi ptujskemu Orfejevemu spomeniku in tako omogoča prepoznavanje nekaterih podrobnosti, ki na njem danes niso več razvidne (sl. 9-10). ${ }^{49}$

$\mathrm{Na}$ Orfejevem spomeniku so upodobljene naslednje živali: na desni veji sedijo opica in dve ptici, okoli leve pa se ovija kača; na njej sta še gos z razprtimi krili in neka ptica. Od desne proti levi glede na pevca si sledijo neka velika mačka, slon, lev, gazela, lisica in bik. Na levi so merjasec, ovca, enogrba kamela in pes ali volk. Orfej sedi na skali, oblečen je v krajšo tuniko, plašč in hlače, na sebi ima frigijsko čepico. Kithara mu počiva na levem stegnu, z levico drži za glasbilo, z desnico pa ubira strune.

47 ŠAŠEL KOS 1993 (op. 41), str. 224; Marjeta ŠAŠEL KOS, Poetovio before the Marcomannic Wars. From Legionary Camp to Colonia Ulpia, Trajan und seine Städte (ur. Ioan Piso, Rada Varga), Cluj-Napoca 2014, str. 155-156.

48 Pevca obkrožajo istorodne živali, le da jih je manj. Pod slonom sedi velika mačka neznane vrste, medtem ko zver na Orfejevem spomeniku stoji. Na ptujski steli sta še lisica nad bikom in ovca pod kamelo.

49 CONZE 1875 (op. 41), str. 7; Arnold SCHOBER, Die römischen Grabsteine von Noricum und Pannonien, Wien 1923, str. 67, kat. št. 142; ABRAMIĆ 1925 (op. 43), str. 138; SCHOELLER 1969, (op. 20), str. 28; PANYAGUA 1973 (op. 20), str. 449, kat. št. 170; Stanko PAHIČ, Seznam rimskih kamnov v Podravju in Pomurju, Arheološki vestnik, 28, 1977, str. 58; KASTELIC 1998 (op. 43), str. 484-485; VIEILLEFON 2003 (op. 18), str. 186, kat. št. R14. O epitafu gl. HOFFILLER, SARIA 1938 (op. 43), str. 43-44, kat. št. 101; Inscriptiones Asiae, provinciarum Europae Graecarum, Illyrici Latinae /.../ consilio et auctoritate Academiae Litterarum Regiae Borussicae. Inscriptionum Illyrici partes VI-VII. Res gestae divi Augusti, Edictum Diocletiani de pretiis rerum. Privilegia militum veteranorumque, Instrumenta Dacica comprehendens (ur. Theodor Mommsen), Berolini 1873 (Corpus inscriptionum Latinarum, III/2), kat. št. 5292; Inscriptionum Orientis et Illyrici latinarum supplementum, Berlin 1902 (Corpus inscriptionum Latinarum, Supplementum), kat. št. 11708; ŠA ̌̌EL KOS 1993 (op. 41), str. 224. 


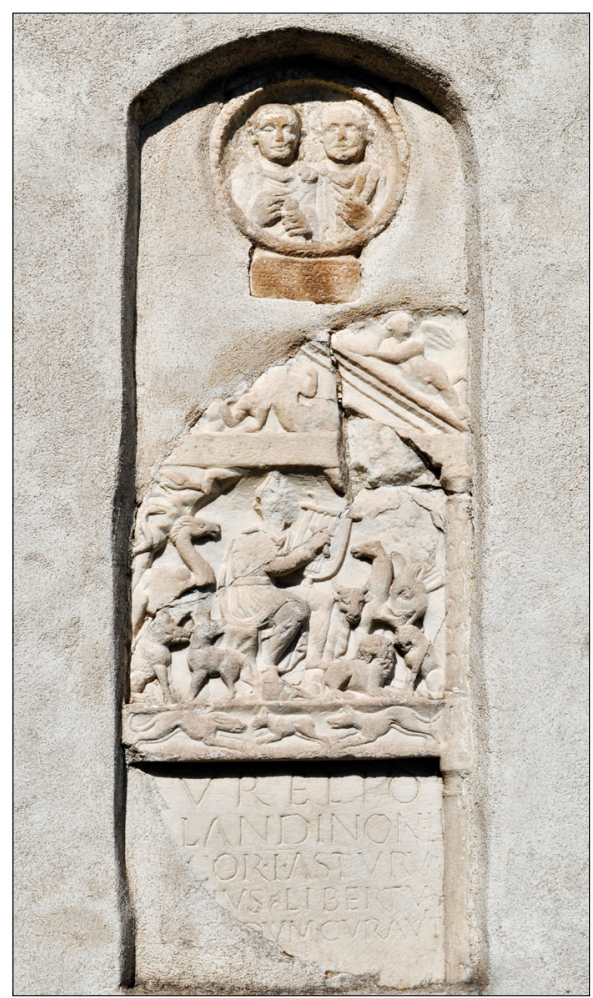

9. Stela Avrelija Kalandina, 3. stoletje, Šmartno na Pohorju

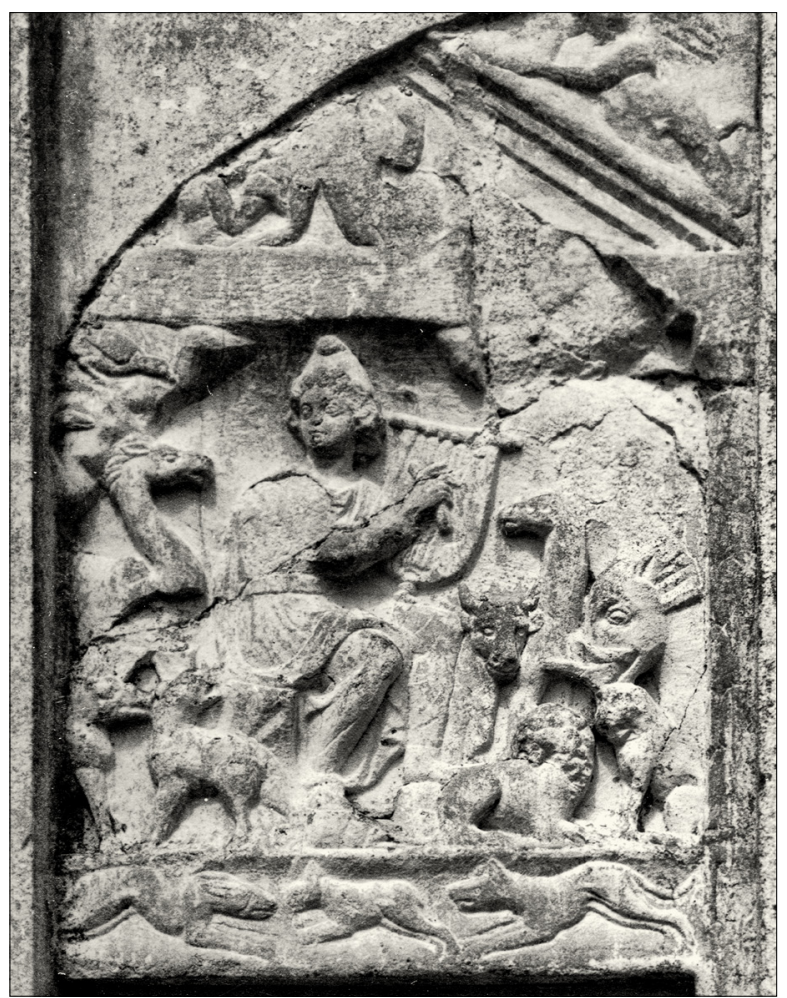

10. Orfej med živalmi, stela Avrelija Kalandina, 3. stoletje, Šmartno na Pohorju

V Filostratovi ekfrazi poleg dreves na relief več kot očitno spominja tudi opis Orfejeve drže, ki popolnoma ustreza večini primerkov iz skupine II b:

Leva noga počiva na tleh in podpira kitharo, ki sloni na stegnu, desna noga pa z udarjanjem s sandalom ob tla narekuje ritem. Desna roka trdno drži plektron in si prizadeva za melodijo; komolec je iztegnjen, zapestje je upognjeno navznoter. Leva roka pa z iztegnjenimi prsti brenka na strune (Imag. 6).

Glede na nesporne skladnosti s prizorom na Šmartnem na Pohorju lahko sklepamo, da je ptujski Orfej po vzoru iz opisa v ekfrazi skoraj zagotovo nosil sandale, desno roko, v kateri drži plektrum, pa je imel iztegnjeno in z zapestjem obrnjeno navznoter.

Nič pa žal ne moremo reči o barvni skali, saj se prvotna polihromacija ni ohranila. Pevčeve podobe v nasprotju z mozaiki tako ni mogoče celostno primerjati s Filostratovim opisom mladega Orfeja. Čeprav ni slika, ki jo opisuje Filostrat Mlajši, najverjetneje nikoli zares obstajala, pa prav Orfejev spomenik kaže neizpodbitno podobnost $s$ to literarno predstavitvijo - tako v pogosteje zastopanih karakteristikah, kot sta drža in oprava, kot tudi v redkejših detajlih, kakršni sta drevesi nad pevcem. Posredno ujemanje govori tudi v prid kasnejšemu času nastanka nagrobne stele, ${ }^{50}$ saj so vsi primerki iz skupine II b nastali šele od poznega 2. stoletja naprej, Filostratov opis pa bi lahko nastal šele v 3. ali celo v zgodnjem 4. stoletju.

50 Gl. Katarina ŠMID, The Orpheus Monument in Ptuj. Some new Observations, Akten des 15. Internationalen Kolloquiums zum Provinzialrömischen Kunstschaffen Der Stifter und sein Monument. Gesellschaft - Ikonographie Chronologie (ur. Peter Scherrer, Barbara Porod), Graz 2019 (Schild von Steier, 9), str. 394-397. 
Žal je Orfejev spomenik danes v zelo slabem stanju, vendar lahko kljub obrabljenosti osrednjega reliefa še vedno prepoznamo visoko kvaliteto izdelave in kamnosekove veščine. Eno izmed številnih vprašanj, ki se ob njem porajajo, je tudi, ali je kipar poznal Filostratovo ekfrazo ali pa se je morebiti naslonil na kak drug, neohranjen likovni vir, ki bi ga lahko spoznal na kateri od vajeniških poti in iz katerega bi navsezadnje lahko do neke mere črpal tudi Filostrat Mlajši.

\title{
Orpheus among the Animals on the Orpheus Monument in Ptuj: An Echo of the Ekphrasis by Philostratus the Younger?
}

\author{
Summary
}

One of the Imagines (Imag. 6) in Eikóvec by Philostratus the Younger precisely describes the painting of Orpheus among the animals that supposedly hung in a private collection in Neapolis (nowadays Naples). Owing to the relatively high number of preserved depictions of the motif in the mosaic painting, several Roman mosaics are assumed to be possible derivatives of that painting. In particular, regarding Henri Stern's classification, the entire, though rare, mosaic-group II b, would take after it. The group dates from the late $2^{\text {nd }}$ century (the mosaic from Leptis Magna) until the $4^{\text {th }}$ or even $5^{\text {th }}$ century (the mosaic from Kissamos in Crete). However, his classification was also applied to other media bearing that motif. Almost all of the representatives of group II b also share the type of Phrygian Orpheus, as well as the posture of the musician, which, once again, matches the Philostratus' ekphrasis: his left foot resting on the ground supports the lyre which rests upon his thigh, his right foot marks the time by beating the ground with its sandal, and, of the hands, the right one is firmly grasping the plectrum gives close heed to the notes, the elbow extended and the wrist bent inward, while the left with straight fingers strikes the strings (translated by Arthur Fairbanks).

Among the several mosaics bearing that motif, which were widespread across the entire Roman Empire from the middle of the $2^{\text {nd }}$ century until the end of the $4^{\text {th }}$ century or even later, the mosaic in Philippopolis in the province of Arabia (Shahba, in situ) matches Philostratus' description to the greatest extent, as has been pointed out several times in previous scholarly literature. Its dating spans from the reign of Philip the Arab (244-249), the founder of the city, till the $4^{\text {th }}$ century. The scene corresponds closely to Philostratus' ekphrasis regarding the posture of the singer, his garment, as well as the colour scale. Henri Stern already stressed the painting's similarities to the mosaics from Blanzy-lès-Fismes (Musée archéologique de Laon), dating around 300-350, whereas Ursula Liepmann pointed out the analogies with the mosaic from the unknown site in northern Syria (now Hannover, Museum August Kestner, inv. nr. 1970.48), dating from 397 A.D. 
However, not only the posture, but also some of the animals (lion, boar, wolf, birds) and especially the tree branches that span above the scene, accommodate the birds and form a semicircle: Accordingly, pine and cypress and alder and poplar and all the other trees stand about Orpheus with their branches joined like hands, and thus, without requiring the craft of man, thy enclose for him a theatre, that therein the birds may sit on their branches and he may make music in the shade (translated by Arthur Fairbanks).

The latter, which are relatively rare and are uncommon to the group II b, nor are they present in the Arabian mosaic, are clearly visible on the main relief of the Orpheus monument in Poetovio (today Ptuj), the grave stele, erected for Poetovian duovir and decurio. Even though the stele is heavily abraded due to the climate conditions and its secondary purpose as a pillory in the Middle Ages, the recognition of some of the poorly visible details is possible by comparing it to the more modest stele of Aurelius Kalandinus, the veteran of Cohors I Asturum, in Šmartno na Pohorju (immured in the parish church of St. Martin) from the $3^{\text {rd }}$ century. The latter, doubtless in a reduced form, takes after the Orpheus monument. Even though in previous descriptions it is mostly stated that Orpheus in Ptuj plays to the animals within the cave or rather in the place that resembles it, which in all probability originates in Alexander Conze's annotation from $1875(, / . . /$ ist wie von einer Grotte überwölbt“), it is far more plausible that the scene is set under the tree branches that enclose for him a theatre and on whose branches the birds perch.

Although not even the slightest vestige of the original colouring has been preserved, the Poetovian stele exhibits several analogies with Philostratus' description. To my knowledge, no other Roman depiction of Orpheus among the animals matches Philostratus' imago to such a degree as the Orpheus monument. Despite the fact that the panel painting in the private gallery in Neapolis in all probability never existed and that Philostratus was only well-acquainted with the contemporary painting, whereas his ekphrasis is based on several pictorial, as well as literary sources (although no one concrete work can be pointed out), one of the remaining questions is whether the stonemason of the Orpheus monument was familiar with his description, or whether he leaned on some other visual sources, maybe on the same as Philostratus. Nevertheless, the analogies also speak in favour of the later dating, as group II $\mathrm{b}$ is dated from the late $2^{\text {nd }}$ century onwards and Philostratus' Imagines were written in the $3^{\text {rd }}$ or even in the early $4^{\text {th }}$ century. 
115. Zupn L ured, srotorree

2 zorons

116. Zupn 1 ured, svoAnton, S1 ov, Gorlce Razne slovenačke knjige

117. Srez Gornji Grad Sreska arhiva

118. Zupní ured, Orelse

ᄂ 3 orkvena ruh:

119. Tranciskenski samostan, Nazarje

L Razne teólöke knjige

120. Lupni ured sv.Jakob, Pameče
4 2vona

121. Zupni ured, Vransko

5 zvona

122. Zupni ured, Naklo

razne crkvena stvari

123. Zamak Otočes, Novo Nes to

Kul turno istoriski inventar

124. Zupni ured stolovrenc, Slovoforice Misu restitulsane

$\checkmark$ Slovenecke beletristicke knjige

125. Zupni ured, Tehar APPARATUS tuisano 1949

b. povelja cara Sranje

126. Zupni ured, Komenda

126. Tapai uned, Knjlge

227. Župhi ured, Joz1rje 7 zrona

128. Zupni ured, Kranj
Razne crkvene stvar 1

129. Zupns ured, Bizeljsko 3 z vona

130. Żupn1 ǔred, Hajs̆perts 2 kaleža 1 dr.

131. Drógodínja trgoračka tikola, Colje Nisu restitulagne 2907 knjlga

132. Zupni ured, 8 r.Jah

Misu. restituisana

133. Zamak Bogea šperk

Cel ok upni inven tar zamka

134. Lupni ured, Beče

1340 200 knjlga 120 zbirk1 lept1ra

235. Zupal ured,aroJurif kod Celja 5 a vona

Misu restituiame

Nisu rest1 tut $\operatorname{sen}$ a

Nian rest1 tulsan a

Nisu restitus ans

Igto isao bro.22

N1 24 reat 1 tud and

IIsu restituisana
K1ar rest1 tuisang

Risu rest tusane

If

N1 je restituisano

Restituisan yedán deo

Nisu resti tul sana

Higu restitulsana

Nisu restituisane

Ne priznaju pravo rest tucl je

Buxbers Nisu restituisane

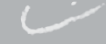

$\sim$

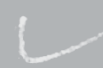





\section{IZVLEČKI IN KLJUČNE BESEDE} ABstracts AND KEYWORDS

\author{
Boris Golec \\ Višnjegorski slikarji 17. in 18. stoletja, njihovo socialno \\ in naročniško okolje. \\ Frančišek Karel (Francesco) Faenzi, Franc Faenzi, Janez \\ Jakob Menhard (Mönhardt), Jakob Killer, Karel Ludvik \\ Gentilli, Peter Straspurger, Franc Anton Nirenberger, \\ Franc Ksaver Nirenberger, Anton Nirenberger
}

1.01 Izvirni znanstveni članek

Prispevek obravnava devet slikarjev, izpričanih v kranjskem mestecu Višnja Gora od leta 1644 do leta 1790. Razen dveh so bili med seboj vsi sorodstveno povezani, čeprav je šlo le v dveh primerih za zaporedni generaciji, pri družini Faenzi iz 17. stoletja za očeta in sina, pri družini Nirenberger iz 18. stoletja pa za očeta in dva sinova. Druge sorodstvene vezi so se spletle s svaštvom in porokama $\mathrm{z}$ vdovama slikarjev.

V Višnji Gori delujoči slikarji niti v kranjskem regionalnem merilu niso bili prvovrstni umetniki svojega časa. Dela štirih niso ohranjena oziroma niso identificirana kot njihova. Delo najstarejšega, Francesca Faenzija, poznamo samo iz pisnih virov; ohranjena sta dva pozlačena oltarja Janeza Jakoba Menharda in več del Antona Nirenbergerja, ki je deloval na Gorenjskem, vse obravnavane slikarje pa po kvantiteti in kvaliteti presega Franc Anton Nirenberger, čigar slike in pozlatitve oltarjev najdemo v širokem geografskem prostoru dežele Kranjske. Prištevati ga je mogoče med boljše slikarje, katerih slikarstvo je šlo v korak z umetnostnim razvojem poznega baroka. Prispevek obravnava tudi gmotne razmere slikarjev in njihovo vključenost $\mathrm{v}$ družbeno okolje.

Ključne besede: slikarji, socialno okolje, naročniki, Višnja Gora, rodbina Faenzi, Johann Jakob Menhard, Jakob Killer, Peter Straspurger, rodbina Nirenberger

\author{
Boris Golec \\ $17^{\text {th }}$ and $18^{\text {th }}$ Century Painters from Višnja Gora, their \\ Social Environment and Commissioners. \\ Franz Karl (Francesco) Faenzi, Franz Faenzi, Johann \\ Jakob Menhard (Mönhardt), Jakob Killer, Karl Ludwig \\ Gentilli, Peter Straspurger, Franz Anton Nirenberger, \\ Franz Xaver Nirenberger, Anton Nirenberger
}

1.01 Original scientific article

The paper analyses nine painters attested in Višnja Gora from 1644 to 1790 . With the exception of two, all of the others were related, even though in only two cases were there two generations; a father and son in the Faenzi family in the $17^{\text {th }}$ century, and a father and two sons in the Nirenberger family in the $18^{\text {th }}$ century. Other family ties were created by marriage and two weddings to the painters' widows.

The painters working in Višnja Gora were not highquality artists of their time, not even within Carniolan regional standards. The works of four of them are not preserved or have not been identified. The work of the oldest among them, Francesco Faenzi, is known only through written sources, while two gilded altars by Johann Jakob Menhard are preserved, and several works are also known by Anton Nirenberger who worked in Upper Carniola. All these painters were surpassed in quantity and quality by Franz Anton Nirenberger, whose paintings and the gildings of altars can be found in a wide geographical area of Carniola. He can be considered one of the better painters whose paintings followed the artistic development of the late Baroque. The paper also analyses the painters' financial situation and their integration in their social environment.

Keywords: painters, social context, art patronage, Višnja Gora, Faenzi family, Johann Jakob Menhard, Jakob Killer, Peter Straspurger, Nirenberger family 


\section{Renata Komić Marn}

"Če bo hotel muzej pridobiti kaj boljših stvari, bo moral za nakup tvegati večje vsote."

Nakupi za Narodni muzej na dražbi Szapáryjeve zbirke $v$ Murski Soboti

\subsection{Izvirni znanstveni članek}

V letih 1930 in 1931 je v gradu Murska Sobota na skrajnem vzhodu Dravske banovine v Kraljevini Jugoslaviji potekala javna dražba. Razprodajali so premično premoženje madžarskega državljana in veleposestnika grofa Ladislava Szapáryja, lastnika murskosoboškega gradu. Analiza dražbenega/prodajnega zapisnika, cenilnega kataloga in drugega $\mathrm{z}$ razprodajo povezanega gradiva prinaša dragocene podatke o grofovi zbirki in osvetljuje poti, po katerih so umetnine zapustile grad v Murski Soboti. Poleg tega postavlja izhodišča za ugotavljanje njihove poznejše usode in pogosto tudi sedanjega hranišča. Tako je bilo mogoče sestaviti popoln seznam predmetov iz Szapáryjevega gradu, ki jih je na dražbi leta 1930 nakupil Josip Mal, ravnatelj Narodnega muzeja v Ljubljani, in jih natančneje predstaviti. Čeprav se je Mal precej prenaglil pri kupovanju in negospodarno porabil sredstva, ki jih je imel na razpolago, pa je bil izbor predmetov premišljen, daljnosežen in utemeljen, saj gre večinoma za izjemne umetnine, ki si zaslužijo več pozornosti, kot so je bile deležne doslej.

Ključne besede: Ladislav Szapáry (1864-1939), Josip Mal (1884-1978), dražbe, grad Murska Sobota, Narodni muzej Slovenije, starinsko pohištvo

\section{Katarina Šmid}

Orfej med živalmi na ptujskem Orfejevem spomeniku upodobitev ekfraze Filostrata Mlajšega?

\subsection{Izvirni znanstveni članek}

Prispevek obravnava osrednji prizor Orfeja med živalmi na Orfejevem spomeniku na Ptuju (rimska Petoviona) in njegovo ujemanje s sliko, ki jo opisuje Filostrat Mlajši v svojem delu Eỉkóves in ki naj bi visela v neki zasebni galeriji v Neapolisu. Filostratova ekfraza naj bi se ikonografsko ujemala $\mathrm{z}$ relativno redko zastopano skupino II b iz motivne klasifikacije Henrija Sterna, Orfej pa naj bi sodil v t. i. frigijski tip. Po Sternu je osnovni zgled za to skupino tabelna slika, ki jo opisuje Filostrat Mlajši, ali pa morebiti neka starejša slika, ki je vplivala nanjo. Kot najboljše primerjave so bili izpostavljeni mozaiki iz Blanzy-lès-Fismesa, neznanega najdišča v severni Siriji

\section{Renata Komić Marn}

"If the museum wishes to obtain better things, it will have to risk higher sums."

The Acquisitions for the National Museum at the Auction of the Szapáry Collection in Murska Sobota

1.01 Original scientific article

In 1930 and 1931, a public auction was held at the Murska Sobota Castle in the far east of the Drava Banate in the Kingdom of Yugoslavia. The movable property of the Hungarian citizen and landowner Count Ladislav Szapáry, the owner of the Murska Sobota Castle, was being sold off. The analysis of the sales records, auction catalogue and other materials connected to the auction, brings about valuable information about the Count's collection and illuminates the way through which the artworks left the castle in Murska Sobota. It also presents the starting point for finding out the items' subsequent fate and, oftentimes, their present location. It was thus possible to compile a complete list of the objects from Szapáry's castle, which Josip Mal, the director of the National Museum in Ljubljana, purchased at the auction in 1930, and present them in detail. Even though Mal acted rather hastily when buying the items and spent the means that were at his disposal, his selection of objects was deliberate, far-reaching and valid, since it primarily consists of exceptional works of art that deserve greater attention than they have received so far.

Keywords: Ladislav Szapáry (1864-1939), Josip Mal (1884-1978), auctions, Murska Sobota Castle, National Museum of Slovenia, antique furniture

\section{Katarina Šmid}

Orpheus among the Animals on the Orpheus Monument in Ptuj: An Echo of the Ekphrasis by Philostratus the Younger?

1.01 Original scientific article

The article discusses the central motif of Orpheus among the animals on the Orpheus monument in Ptuj (Roman Poetovio) and its analogies with the imago that supposedly hung in a private gallery in Neapolis and was precisely described by Philostratus the Younger in his Eikóvec. Philostratus' ekphrasis should (regarding the classification of the motif by Henri Stern) match the relatively rarely represented group II b and Orpheus should belong to the type of the so-called Phrygian Orpheus. According to Stern, an archetype for the whole group would be the panel painting, described by Philostratus the Younger or perhaps the more ancient one that influenced his ekphrasis. 
in Shahbe. Tudi nekatere živali, ki so upodobljene na Orfejevem spomeniku (lev, merjasec, volk, ovca, ptice), in drugi detajli (drevesne veje, ki se bočijo nad prizorom in na katerih sedijo ptice) so pri Filostratu izrecno omenjeni, glasbenikova drža pa se v vseh podrobnostih ujema tako s skoraj vsemi primerki iz skupine II b kot tudi s Filostratovo ekfrazo.

Ključne besede: Orfej, Orfejev spomenik, Orfej med živalmi, Filostrat Mlajši, Petoviona, ekfraza, Imagines, Eikóveৎ

\author{
Barbara Vodopivec \\ Restitucija predmetov kulturne dediščine iz Avstrije v \\ Jugoslavijo po letu 1945
}

\subsection{Izvirni znanstveni članek}

Prispevek obravnava restitucijo predmetov kulturne dediščine iz Avstrije v Jugoslavijo po letu 1945. Ugotovitve predstavljajo podlago za nadaljnje umetnostnozgodovinske raziskave provenience. Prispevek izhaja iz kritične analize arhivskega gradiva, ki v tem kontekstu še ni bilo interpretirano in ki ga hranijo Arhiv Jugoslavije, Arhiv Republike Slovenije in Informacijsko-dokumentacijski center za dediščino Ministrstva Republike Slovenije za kulturo. V ospredje postavlja osvetlitev okoliščin, v katerih je potekala restitucija, rekonstrukcijo ključnih akterjev in ustanov ter oceno stopnje realizacije zahtevkov za vračilo predmetov kulturne dediščine, ki jih je proti Avstriji vložila Jugoslavija oziroma Slovenija. Pri tem izpostavlja vzroke za stanje in tako poglablja razumevanje procesa restitucije. Odgovore vpenja v širši kontekst rekonstrukcije povojne Evrope, od vloge zaveznikov in političnega, zakonodajnega ter diplomatskega oblikovanja nove države Jugoslavije do soočenja Evrope $\mathrm{z}$ vojno škodo in s tem povezanega vzpostavljanja novih identitet ter doktrine varstva kulturne dediščine. Zaradi velikega obsega arhivskega gradiva se prispevek osredotoča na analizo dokumentov jugoslovanske strani.

Ključne besede: restitucija umetnin, provenienca, transfer predmetov kulturne dediščine, Ivan Kreft, restitucijska pogajanja, restitucijska delegacija, Jugoslavija, Zdenka Munk, Franjo Baš, Pavle Blaznik
The best comparisons so far were pointed out to be the mosaics from Blanzy-lès-Fismes, from the unknown site in northern Syria, and Shahba. Interestingly, some of the animals (lion, boar, wolf, sheep, birds) and other details (branches with the sitting birds above the scene), especially mentioned in Philostratus' description, are also present in the Orpheus stele in Poetovio. Nevertheless, his posture also corresponds completely to almost all of the representatives of group II b, as well as to the Philostratus' ekphrasis.

Keywords: Orpheus, Orpheus Monument, Orpheus among the animals, Philostratus the Younger, Poetovio, ekphrasis, Imagines, Eỉóveৎ

\section{Barbara Vodopivec}

Restitution of Objects of Cultural Heritage from Austria to Yugoslavia after 1945

\subsection{Original scientific article}

The paper discusses the restitution of objects of cultural heritage from Austria to Yugoslavia after 1945. The findings present a basis for further art historical research of provenance. The paper is based on a critical analysis of archival sources kept in the Archives of Yugoslavia, the Archives of the Republic of Slovenia and the Heritage Information and Documentation Centre (INDOK Centre) of the Ministry of Culture of the Republic of Slovenia, which have not yet been interpreted in this context. The paper focuses on the circumstances in which the restitution was carried out, crucial protagonists and institutions, and offers the quantitative analyses of the realization of restitution claims for objects of cultural heritage that were filed by Yugoslavia or Slovenia against Austria. The paper attempts to pinpoint the reasons for such a state and, thus, deepens our understanding of the restitution process. The answers are incorporated into the wider context of the reconstruction of post-war Europe, from the role of the allies, the political, legislative and diplomatic formation of the new state of Yugoslavia, to Europe facing war damage and the establishment of new identities as well as the doctrine of the protection of cultural heritage connected to the latter. Due to the abundance of surviving archival sources, the paper focuses on the analysis of the Yugoslav documents.

Keywords: restitution of artworks, provenance, transfer of cultural heritage objects, Ivan Kreft, restitution negotiations, restitution delegation, Jugoslavia, Zdenka Munk, Franjo Baš, Pavle Blaznik 


\author{
Jure Volčjak \\ Cerkve goriške nadškofije na Kranjskem v času nadškofa \\ Karla Mihaela grofa Attemsa. \\ 1. del: Bistrski, gorenjski in metliški arhidiakonat
}

\subsection{Pregledni znanstveni članek}

V obsežnejšem članku, ki bo razdeljen na tri dele, bodo predstavljene cerkve goriške nadškofije na Kranjskem, ki so omenjene v vizitacijskih zapisnikih prvega goriškega nadškofa Karla Mihaela grofa Attemsa (17521774). V prvem delu prikazujemo cerkve arhidiakonata kartuzije Bistre, gorenjskega arhidiakonata in arhidiakonata nemškega viteškega reda v Beli krajini. Na začetku članka so prikazani patrociniji oziroma titulature oltarjev na osnovi liturgične hierarhije, sledi predstavitev posameznih cerkva po začrtani strukturi.

Ključne besede: cerkve, goriška nadškofija, 18. stoletje, Karel Michael grof Attems, Bela krajina, Kranjska, bistrski arhidiakonat, gorenjski arhidiakonat, metliški arhidiakonat

\section{Jure Vuga}

Podoba samogiblive skulpture malika, mehaničnega

čudesa ali »avtomata« na Kranjskem oltarju

\subsection{Izvirni znanstveni članek}

$\mathrm{Na}$ dveh ohranjenih lesenih tablah t. i. Kranjskega oltarja, krilnega oltarja župnijske cerkve sv. Kancijana v Kranju (Belvedere, Dunaj), sta upodobljena beg in mučeništvo svetnikov Kancija, Kancijana, Kancijanile in Prota, ki so pobegnili iz Rima in zavrnili čaščenje Jupitrovega kipa. Rumeno obarvan kovinski kipec malika na prizoru njihovega mučeništva je umetnik upodobil na zobatem kolesu, ki ob vrtenju povzroča zvončkljanje kraguljčkov na štirih navpičnih oseh ob robovih kapitela. Slikarjev namen je bil poudariti poznavanje legendarnih zgodb o gibljivih skulpturah, ki zvonijo z zvonci, kot so Salvatio Romae (opisani v vodnikih za romarje, znanih kot $\mathrm{Mi}$ rabilia Urbis). Z mehaničnimi čudesi, ki so se razširila po Evropi v 15. in zgodnjem 16. stoletju, so najpogosteje opremili mestne ure in orgle. Mojster Kranjskega oltarja je zelo verjetno nekaj časa bival v Nürnbergu, kjer je na lastne oči videl še danes ohranjene gibljive figure, ki so del urnega mehanizma na pročelju tamkajšnje Marijine cerkve.

\section{Jure Volčjak}

The Churches of the Archdiocese of Gorizia in Carniola in the Time of Archbishop Karl Michael von Attems. Part 1: The Archdeaconry of Bistra, Upper Carniola (Gorenjska) and Metlika

\subsection{Review article}

The churches of the Archdiocese of Gorizia in Carniola, mentioned in the visitation records of the first archbishop of Gorizia, Karl Michael von Attems (1752-1774), will be presented in an extensive article, which will be divided into three parts. The churches that stood in the archdeaconry of the Bistra Carthusian monastery, the archdeaconry of Upper Carniola, and the archdeaconry of the German Teutonic Order in Bela krajina will be presented in Part 1. The patrocinia or the titulature of the altars are presented at the beginning of the article based on liturgical hierarchy, followed by introductions of individual churches according to the outlined structure.

Keywords: churches, Archdiocese of Gorizia, $18^{\text {th }}$ century, Karl Michael von Attems, Bela krajina, Carniola, archdeaconry of Bistra, archdeaconry of Upper Carniola (Gorenjska), archdeaconry of Metlika

\section{Jure Vuga}

A Depiction of a Self-moving Sculpture of an Idol, a Mechanical Marvel or Automaton in the Krainburg Altarpiece

\subsection{Original scientific article}

Around 1500, the Master of the Krainburg Altarpiece produced two wooden panels, parts of a lavish Gothic altarpiece for the parish church of Saint Cantianus in Kranj (Germ. Krainburg), which are now kept in the Belvedere in Vienna. According to legend, the saints Cantius, Cantianus, Cantianilla and Protus escaping from Rome refused to worship a statue of Jupiter. In the scene of their martyrdom, the artist depicted a metal-like statuette on a cogwheel mechanism, which can be made to rotate, causing the ringing of the bells on the vertical levers along the four sides of the pedestal. The intention of the painter was to emphasize his acquaintance with legendary stories about moving statues with ringing bells, like the Salvatio Romae (described in guides for pilgrims known as Mirabilia Urbis). Mechanical figures spread around Europe in the $15^{\text {th }}$ and early $16^{\text {th }}$ century and were mostly part of municipal or church clocks and organs. The master of the Krainburg altarpiece had most probably lived in Nuremberg for some time and had seen moving figures as part of the clock mechanism on the façade of the Our Lady cathedral. 
Ključne besede: poznogotsko slikarstvo, severna renesansa, mehanična čudesa, avtomati, tehnična zgodovina, Mojster Kranjskega oltarja, gotski malik, avtoportret, Salvatio Romae
Keywords: late Gothic painting, northern Renaissance, mechanical marvels, technical automata, history of technology, Master of the Krainburg Altarpiece, Gothic idol, self-portrait, Salvatio Romae 



\section{SODELAVCI}

\section{CONTRIBUTORS}

Izr. prof. dr. Boris Golec

ZRC SAZU,

Zgodovinski inštitut Milka Kosa

Novi trg 2

SI-1000 Ljubljana

boris.golec@zrc-sazu.si

Dr. Renata Komić Marn

ZRC SAZU,

Umetnostnozgodovinski inštitut Franceta Steleta

Novi $\operatorname{trg} 2$

SI-1000 Ljubljana

renata.komic@zrc-sazu.si

Doc. dr. Katarina Šmid

Univerza na Primorskem,

Fakulteta za humanistične študije

Titov $\operatorname{trg} 5$

SI-6000 Koper

katarina.smid@fhs.upr.si

Dr. Barbara Vodopivec

ZRC SAZU,

Umetnostnozgodovinski inštitut Franceta Steleta Novi $\operatorname{trg} 2$

SI-1000 Ljubljana

barbara.vodopivec@zrc-sazu.si

Dr. Jure Volčjak

Arhiv Republike Slovenije

Zvezdarska 1

SI-1002 Ljubljana

jure.volcjak@gov.si

Dr. Jure Vuga

Kvedrova 16

SI-6000 Koper

jurevug@yahoo.com 



\section{VIRI ILUSTRACIJ \\ PHOTOGRAPHIC CREDITS}

\section{Boris Golec}

1: J. W. Valvasor, Topographia Ducatus Carnioliae Modernae, Wagensperg 1679.

2: (C) Arhiv Republike Slovenije, Ljubljana (foto: Boris Golec).

3, 6: (C) Nadškofijski arhiv Ljubljana (foto: Boris Golec).

4, 5, 7: Boris Golec.

8: (C) ZRC SAZU, Umetnostnozgodovinski inštitut Franceta Steleta, Ljubljana (foto: Andrej Furlan).

\section{Renata Komić Marn}

1, 8, 10-11, 13-16, 21: (C) Narodni muzej Slovenije, Ljubljana (foto: Tomaž Lauko).

2, 9, 17-19, 23: (C) Narodni muzej Slovenije, Ljubljana, fotodokumentacija OZUU NMS.

3, 5-6, 12, 22: () INDOK center, Direktorat za kulturno dediščino, Ministrstvo za kulturo Republike

Slovenije, Ljubljana (foto: France Stele).

4, 7: (C) Fortepan / Budapest Főváros Levéltára (Mestni arhiv Budimpešta).

20: Vasárnapi Újság, 55/2, 12. 1. 1908.

24: (C) Narodna galerija, Ljubljana (foto: Bojan Salaj).

\section{Katarina Šmid}

1: CMusée d'art et d'archéologie de Laon, Laon (foto: Gilles Mermet).

2: Laurence Vieillefon, La figure d'Orphée dans l'antiquité tardive, Paris 2003.

3: Wikimedia Commons.

4: (C) Museum August Kestner, Hanover (foto: Christian Tepper).

5-6: () ZRC SAZU, Umetnostnozgodovinski inštitut Franceta Steleta, Ljubljana (foto: Andrej Furlan).

7-8: (C) Steiermärkisches Landesarchiv, Graz.

9: Franci Lazarini.

10: (C) ZRC SAZU, Inštitut za arheologijo, fototeka.

\section{Barbara Vodopivec}

1: (C) Arhiv Jugoslavije, Beograd (foto: Barbara Vodopivec).

2: (C) Arhiv Republike Slovenije, Ljubljana (foto: Barbara Vodopivec).

3-4: (C) INDOK center, Direktorat za kulturno dediščino,

Ministrstvo za kulturo Republike Slovenije, Ljubljana.

\section{Jure Vuga}

1-3: (C) Österreichische Galerie Belvedere, Dunaj.

4: (C) Fondazione Federico Zeri, Bologna.

5: (C) ZRC SAZU, Umetnostnozgodovinski inštitut Franceta Steleta (foto: Andrej Furlan).

6: () Univerza v Ljubljani, Filozofska fakulteta, fototeka Oddelka za umetnostno zgodovino.

7, 8 (C) Narodna in Univerzitetna knjižnica, Ljubljana (foto: Jure Vuga).

9, 10: (C) Bibliothèque Nationale, Pariz. 


Vse pravice pridržane. Noben del te izdaje ne sme biti reproduciran, shranjen ali prepisan v kateri koli obliki oz. na kateri koli način, bodisi elektronsko, mehansko, s fotokopiranjem, snemanjem ali kako drugače, brez predhodnega dovoljenja lastnika avtorskih pravic (copyright).

All rights reserved. No part of this publication may be reproduced, stored in a retrieval system or utilized in any form or by any means, electronic or mechanical, including photocopying, recording or otherwise, without prior permission of the copyright owner.

Za avtorske pravice reprodukcij odgovarjajo avtorji objavljenih prispevkov.

The copyrights for reproductions are the responsibility of the authors of published papers. 


\section{ACTA HISTORIAE ARTIS SLOVENICA 24|1・ 2019}

\section{Vsebina $\cdot$ Contents}

Katarina Šmid, Orfej med živalmi na ptujskem Orfejevem spomeniku - upodobitev ekfraze Filostrata Mlajšega? • Orpheus among the Animals on the Orpheus Monument in Ptuj: An Echo of the Ekphrasis by Philostratus the Younger?

Jure Vuga, Podoba samogibljive skulpture malika, mehaničnega čudesa ali »avtomata« na Kranjskem oltarju - A Depiction of a Self-moving Sculpture of an Idol, a Mechanical Marvel or Automaton in the Krainburg Altarpiece

Boris Golec, Višnjegorski slikarji 17. in 18. stoletja, njihovo socialno in naročniško okolje. Frančišek Karel (Francesco) Faenzi, Franc Faenzi, Janez Jakob Menhard (Mönhardt), Jakob Killer, Karel Ludvik Gentilli, Peter Straspurger, Franc Anton Nirenberger, Franc Ksaver Nirenberger, Anton Nirenberger $\cdot 17^{\text {th }}$ and $18^{\text {th }}$ Century Painters from Višnja Gora, their Social Environment and Commissioners. Franz Karl (Francesco) Faenzi, Franz Faenzi, Johann Jakob Menhard (Mönhardt), Jakob Killer, Karl Ludwig Gentilli, Peter Straspurger, Franz Anton Nirenberger, Franz Xaver Nirenberger, Anton Nirenberger

Renata Komić Marn, »Če bo hotel muzej pridobiti kaj boljših stvari, bo moral za nakup tvegati večje vsote." Nakupi za Narodni muzej na dražbi Szapáryjeve zbirke v Murski Soboti • "If the museum wishes to obtain better things, it will have to risk higher sums." The Acquisitions for the National Museum at the Auction of the Szapáry Collection in Murska Sobota

Barbara Vodopivec, Restitucija predmetov kulturne dediščine iz Avstrije v Jugoslavijo po letu 1945 • Restitution of objects of Cultural Heritage from Austria to Yugoslavia after 1945

Jure Volčjak, Cerkve goriške nadškofije na Kranjskem v času nadškofa Karla Mihaela grofa Attemsa. 1. del: Bistrski, gorenjski in metliški arhidiakonat - The Churches of the Archdiocese of Gorizia in Carniola in the Time of Archbishop Karl Michael von Attems. Part 1: The Archdeaconry of Bistra, Upper Carniola (Gorenjska) and Metlika

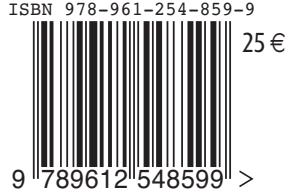

